\title{
Alfred Binet: Charcot's pupil, a neuropsychologist and a pioneer in intelligence testing
}

\author{
Alfred Binet: pupilo de Charcot, neuropsicólogo e pioneiro nos testes de inteligência \\ Hélio A. G. Teive', Gladys M. G. Teive², Norberto Dallabrida², Laurent Gutierrez³
}

\begin{abstract}
The psychologist, Alfred Binet, who worked under the supervision of Prof. Charcot at the end of the $19^{\text {th }}$ century, made several important contributions to neuropsychology, in partnership with Théodore Simon. Most notable among these was the development of intelligence testing scales.
\end{abstract}

Keywords: psychology; neuropsychology; intelligence tests.

\section{RESUMO}

Alfred Binet, psicólogo, que trabalhou sob a supervisão do professor Charcot, no final do século XIX, tem várias importantes contribuições na área de neuro-psicologia, particularmente a criação de escalas com testes de inteligência, com a participação de Théodore Simon.

Palavras-chave: psicologia; neuropsicologia; testes de inteligência.

Jean-Martin Charcot (1825-1893) is world famous as the father of modern neurology. However, although extremely important, his contributions to internal medicine, geriatrics, psychiatry and psychology are less well known ${ }^{1}$. Because of his great intellect and the leadership he exercised among his peers, he had many pupils, some of whom were famous, such as Pierre Marie, Babinski and Gilles de la Tourette, as well as others who stood out in various fields of neuroscience and neuropsychology, like Alfred Binet ${ }^{2}$. This study reviews Alfred Binet's contribution to neuropsychology, particularly his pioneering work with intelligence tests.

\section{ALFRED BINET - A SHORT BIOGRAPHY}

Alfred Binet (1857-1911), the son and grandson of doctors, was born in Nice, which at the time belonged to Italy, and later moved to Paris to pursue his studies (Figure)2. After graduating from law school, he went to medical school, which he gave up to study psychology². Binet was greatly influenced by Théodule Ribot (1839-1916), an experimental psychologist, and Edouard-Gérard Balbini, his doctoral advisor at the Sorbonne. Through Joseph Babinski, a former schoolmate, Binet was introduced to Prof. Charcot at La Salpêtrière Hospital in Paris, where he met and became a great friend of another of Charcot's pupils, Charles Féré2. In Charcot's service, Binet began to attend clinical meetings and acquired an interest in studies of hysteria and hypnosis. He later became very interested in experimental psychology, particularly after Charcot's death in $1893^{2,3}$. He applied several times for a chair of psychology, first at Collège de France as successor to Théodule Ribot, where he competed with Pierre Janet, another of Charcot's pupils, and then at the Sorbonne, where he competed with George Dumas (1866-1946). However, he was unsuccessful on both occasions ${ }^{2,3}$. He later joined the physiological psychology laboratory at the Sorbonne but was not a member of faculty ${ }^{2,3}$.

\section{ALFRED BINET AND JEAN-MARTIN CHARCOT}

Binet took part in various studies of hysteria and hypnosis under Charcot's supervision ${ }^{2}$. He also coauthored studies with Charles Féré (1852-1907), Charcot's private secretary and one of his pupils2. In 1893, Charcot and Binet carried out a study on memory, in which they compared the performance of two expert mental calculators, Jacques Inaudi (1867-1950) and Périclès Diamandi, in tasks involving digit recall ${ }^{4}$. The aim of the study was to investigate different types of memory, and the findings indicated that in arithmetical prodigies, memory for digits was much more developed than other types of memory4.

\footnotetext{
${ }^{1}$ Universidade Federal do Paraná, Hospital de Clínicas, Departamento de Medicina Interna, Serviço de Neurologia, Curitiba PR, Brasil;

2Universidade Estadual de Santa Catarina, Centro de Ciências Humanas e Educação, Florianópolis SC, Brasil;

${ }^{3}$ Université de Rouen, Centre Interdisciplinaire de Recherche Normand en Éducation et Enformation, Rouen, France.

Correspondence: Hélio A.G. Teive; Rua General Carneiro 1103/102; 80060-150 Curitiba PR, E-mail: hagteive@mps.com.br

Conflict of interest: There is no conflict of interest to declare.

Received 12 March 2017; Accepted 31 March 2017.
} 


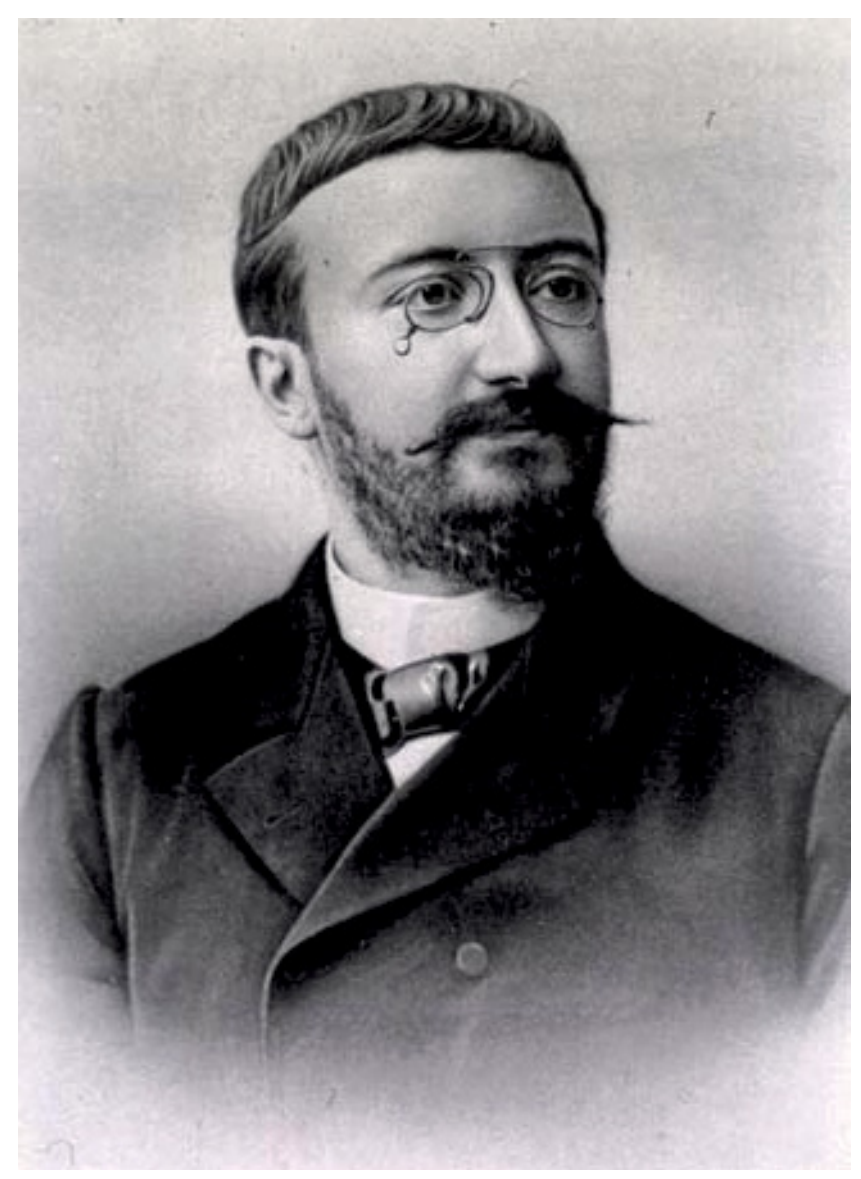

(Extracted from Google Images: www.britannica.com, January, $\left.14^{\text {th }}, 2017\right)$. Figure. Alfred Binet (1857-1911).

Charcot and Binet showed that Inaudi's memory could be classified as auditory while Diamandi's was visual ${ }^{4}$. The study was published in 1893 and translated by Nicolas et al. in $2011^{4}$.

\section{ALFRED BINET AND EXPERIMENTAL PSYCHOLOGY}

While working at the psychology laboratory at the Sorbonne between 1892 and 1904, Binet carried out important studies in experimental psychology applied to education $^{2,3}$. He was, in the words of Silverman and Krenzel ${ }^{5}$, a "prolific pioneer in psychology" and was also recognized as a pioneer in several areas of experimental psychology ${ }^{2,3,5}$. Another area of interest to Binet was child psychology, especially the study of genetic factors and the role played by education in children's cognitive development. In 1895, he published a book under the title Fear in Children ${ }^{2}$.

\section{ALFRED BINET AND COGNITION}

In 1904, with the reform of the French educational system, Binet was appointed coordinator of a commission to study abnormal children and worked on the commission for 20 years ${ }^{2}$. He studied a large number of ordinary people, handicapped children and, at the same time, individuals with special abilities, such as mental calculators, chess players and actors ${ }^{2}$. Two other pupils of Charcot had already taken part in specific studies on children with cognitive dysfunction (mental retardation): first Désiré-Magloire Bourneville (1840-1909) at Bicêtre Hospital, and Paul Sollier (1861-1933), who was considered the first clinical neuropsychologist. ${ }^{2}$ Binet started to carry out studies with a psychiatrist who specialized in mentally retarded children, Théodore Simon (1873-1961). They initially studied cephalometry but later abandoned their studies in this area ${ }^{2}$. Their partnership led them to study and develop a "metric scale of intelligence" 2,6.

\section{THE BINET-SIMON SCALES}

At the Fifth International Psychology Congress in Rome, Italy, in 1905, Sante de Sanctis (1862-1935), an Italian doctor, psychologist and psychiatrist, and Binet, in collaboration with Simon, presented the first intelligence tests to the international scientific community ${ }^{2,6,7}$. The intelligence scale proposed by Binet and Simon, which was based on a series of 30 tests ("Méthodes nouvelles pour le diagnostic du niveau intellectuel des anormaux"), underwent successive improvements, mainly as a result of further studies by Binet, and became an international yardstick ${ }^{2,6,7,8}$. In Brazil, intelligence tests were used during the years 1920-1930 to cope with the increase in the enrollment rate of urban children. In this context, the reform of the primary school becomes a political issue where the tests make it possible to form homogeneous classes ${ }^{9,10}$. In the USA, it was adapted by Terman in 1916 and became known as the Stanford-Binet scale ${ }^{8}$, since when it has undergone successive revisions ${ }^{8}$. In 1939, Wechsler and Bellevue created a new intelligence scale (the Wechsler-Bellevue Intelligence Scale) based on Binet and Simon's pioneering scale that later became better known as the Wechsler scale ${ }^{6,7,8}$.

\section{CONCLUSION}

Alfred Binet, one of Charcot's pupils, who pursued a career in experimental psychology and neuropsychology, is considered to have been a pioneer in this area. He published various important studies, but his most famous achievement was the development of an intelligence scale. This protocol developed progressively on the basis of experiments carried in the Société libre pour l'étude psychologique de l'enfant, of which Binet was the President for 12 years (1900-1911). His friend, Theodore Simon, succeeded him and continued his work. Not really used in France, the intelligence scale met with real esteem in the United States and Latin America after the First World War $2,3,5,6,7,7,110$. 


\section{References}

1. Teive HA, Munhoz RP, Barbosa ER, Little-known scientific contributions of J-M Charcot. Clinics (São Paulo). 2007;62(3):211-4. https://doi.org/10.1590/S1807-59322007000300003

2. Walusinski O. Keeping the fire burning: Georges Gilles de la Tourette, Paul Richer, Charles Féré, and Alfred Binet. Front Neurol Neurosci. 2011;29:71-90. https://doi.org/10.1159/000321778

3. Nicolas S, Sanitioso RB. Alfred Binet and experimental psychology at the Sorbonne laboratory. Hist Psychol. 2012;15(4):328-63. https://doi.org/10.1037/a0028060

4. Nicolas S, Gounden Y, Levine Z. The memory of two great mental calculators: Charcot and Binet's neglected 1893 experiments. Am J Psychol. 2011;124(2):235-42. https://doi.org/10.5406/amerjpsyc.124.2.0235

5. Silverman HL, Krenzel K. Alfred Binet: prolific pioneer in psychology. Psychiatr Q Suppl. 1964;38:323-35.
6. Cicciola E, Foschi R, Lombardo GP. Making up intelligence scales: de Sanctis's and Binet's scales, 1905 and after. Hist Psychol. 2014;17(3):223-36. https://doi.org/10.1037/a0033740

7. Boake C. From the Binet-Simon to the Wechsler-Belleuve: tracing the history of intelligence testing. J Clin Exp Neuropsychol. 2002;24(3):383-405. https://doi.org/10.1076/jcen.24.3.383.981

8. Nicolas S, Ferrand L. Alfred Binet and higher education. Hist Psychol. 2002;5(3):264-83. https://doi.org/10.1037/1093-4510.5.3.264

9. Monarcha C. Brasil arcaico, escola nova: ciência, técnica e utopia nos anos 1920-1930. São Paulo, SP: Ed. UNESP; 2009.

10. Gutierrez L, Melo CSM, Campos RHF. Théodore Simon: promoteur des tests psychologiques dans la formation des maitres brésiliens (Belo Horizonte, 1929). Penser l'Éducation, 2017:39:57-72. 